carry that label as well: apricots, peaches, cherries and almonds.

In Oregon, the filbert nut is now called a hazelnut for marketing purposes, so that may be the case with plums. Back in the 1800s and 1900s, the foothills of the Willamette Valley raised a lot of prunes. I have government bulletins referring to production from 1927, 1931, 1954, 1962, 1968 and 1982. I see ads from California for dried prunes and prune juice.

I would like to see the correct use of prunes and plums, whatever that is. Thank you for the good articles. Keep them accurate and scientific.

There is an old saying, "full of prunes," meaning to talk nonsense. Maybe I am full of prunes.

\section{Glen Mills}

Mills Organic Farm

Newberg, Oregon

Theodore DeJong, UC Cooperative Extension Pomologist, responds: Technically prunes are plums that are used for drying. Specific plums that will dry without fermenting when laid in the sun can also be called prunes. In the commercial trade in most countries, plums used for drying can be called prunes whether they are actually sold fresh or dry. In California, dried prunes have been marketed as dried plums to get away from the idea that they are only for old people who need a laxative. It has nothing to do with being freestone or clingstone.

\section{Labeling biotech crops}

Regarding "Research and adoption of biotechnology strategies could improve California fruit and nut crops," by Haroldsen et al. (April-June 2012): Can California Agriculture disprove the alleged health and environmental risks of genetically modified organisms (GMOs)? We are supporting a "label GMOs" initiative in California, to require all producers to label their products. If the GMO developers and seed manufacturers are confident and proud of their product, why are they spending millions to stop the initiative? Of course this would include transgenics. We buy only organic and are budding organic farmers.

Vazik and Janet Avedisian Arroyo Grande

Lead author Victor Haroldsen and coauthors respond: As we cited in our article, genetically engineered (GE) crops have provided "a reduction of $86.2 \mathrm{mil}$ lion pounds (10.2\%) of pesticide usage and proffer[ed] an associated $21.8 \%$ reduction in the environmental impact quotient." These are demonstrable benefits that should resonate with organic consumers and budding organic farmers. Unfortunately, there is a wide philosophical gap between organic and conventional farmers when it comes to GE crops, even though there is a shared interest in producing safe food with reduced environmental impacts. Mandatory labeling of GE foods in California will present yet another hurdle to the commercialization of improved fruit and nut crops that could be beneficial to California's economy and, in one more way, create a regulatory barrier to innovation in the state.

\section{Switchgrass and CDFA}

Regarding "Switchgrass clarification" (Letters, April-June 2012): While switchgrass is no longer on the California Department of Food and Agriculture (CDFA) noxious weed list, it was included as a B-listed species in 2007 (see CDFA's Noxious Times 8(4):1-9). Interestingly, the plant has never been shown to be invasive in California, where it is not native, but it was placed on the list because of the proposed planting of large acreages as a biofuel species. By putting switchgrass on the state's noxious weed list, CDFA was then able to prevent large-scale cultivation until they were assured that it did not have high potential to become an invasive

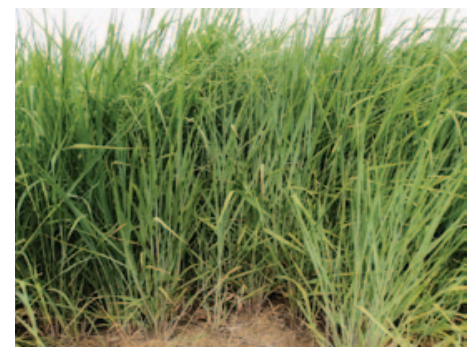

Switchgrass, a promising biofuel, is not considered a noxious weed.

\title{
Three ACE awards for California Agriculture
}

The California Agriculture team has won three awards from the Association for Communication Excellence in Agriculture, Natural Resources, and Life and Human Sciences (ACE), a trade association for land-grant communicators (www.aceweb.org). The awards are:

- Technical publications, bronze; Janet Byron, Robin Meadows, Will Suckow, Hazel White and Janet White: "Food as Medicine: Can what we eat help cure what ails us?" (JulySeptember 2011).

- Writing within a specialized publication, bronze; Robin Meadows: "Biofactors in food linked to health benefits" (July-September 2011).

- Editing, silver; Janet Byron: "California agritourism operations and their economic potential are growing" by Ellie Rilla (April-June 2011).

Managing Editor Janet Byron and Executive Editor Janet White accepted the awards during the 2012 ACE conference in Annapolis, Md. on June 13. 